\title{
EQUiLIBRIUM
}

Quarterly Journal of Economics and Economic Policy

2015 VOLUME 10 ISSUE 3, September

p-ISSN 1689-765X, e-ISSN 2353-3293

www.economic-policy.pl

Guziejewska, B. (2015). Designing a Revenue Structure in Local Self-government Entities in Poland: Taxes Versus Grants. Equilibrium. Quarterly Journal of Economics and Economic Policy, 10(3), pp. 45-63, DOI: http://dx.doi.org/10.12775/ EQUIL.2015.024

Beata Guziejewska*

University of Lodz, Poland

\section{Designing a Revenue Structure in Local Self-government Entities in Poland: Taxes Versus Grants**}

JEL Classification: $H 70 ; H 71 ; H 77$

Keywords: public finance; fiscal relations; grants; local taxes; self-government finance

\begin{abstract}
This paper discusses the problem of rational forming of the financing system for local self-government entities. The concept of fiscal federalism as well as the role and importance of own revenues and revenues from the state budget transfers, which are slightly different from other unitary countries, have been referred to in this context. The aim of this paper is to statistically analyze the selected categories of local self-government revenues in Poland with regard to the local self-government total revenue in 2013 and the total expenditure between 1999 and 2013. The study involved methods for the analysis of dynamics of mass phenomena such as, first of all, fixed base indexes, the average rate of change indicator and the correlation and regression coefficients from time series. The correlation and regression coefficients from time series were calculated with the first difference method. The results of study demonstrate a statistically significant role of transfer revenues in the expenditure (with the exception of voivodeships) and a statistically insignificant effect of sensu stricto own revenues in the case of cities with poviat
\end{abstract}

(C) Copyright Institute of Economic Research \& Polish Economic Society Branch in Toruń Date of submission: April 28, 2015; date of acceptance: August 15, 2015

* Contact: beata.guziejewska@uni.lodz.pl, University of Lodz, Public Finance Department, Rewolucji 1905 r. st., 90-214 Lodz, Poland, Poland

** The paper is a part of research project financed by Polish National Science Center, 2014/13/B/HS4/00162, "The role of the system of financing local government in the creation and perpetuation of fiscal illusion. Complementary of qualitative and quantitative methods". 
status, poviats and voivodeships. The results reveal that the spending policy of local self-governments in Poland is highly dependent on a specific category of revenue, which is referred to as "other revenue" in the study, as a result of the inflow of EU funds. In the long term, once this specific, incidental source of revenue has been exhausted, the local self-government finance may face serious disruption. Such conclusions may serve as a practical contribution to the creation of an early warning mechanism in the shaping of present and future fiscal policies.

\section{Introduction}

The models and instruments of financing local self-government entities have long been a subject of debate. Controversies surround the required level of decentralization as well as the conditions for and the consequences of the fact that local self-government finance is part of the overall system of state public finance. Also the effects produced by the use of specific sources of financing have contributed to a proliferation of both theoretical and practical problems with regard to, first of all, the sources of tax revenues (own revenue), subsidies and grants from the state budget (non-own revenue, transfers). The doctrine postulates a widest possible scope of financial independence of local self-government, which would be defined by the level of own revenue, which, in turn, is important from economic, social and political vantage points. The literature has described a phenomenon known as the flypaper effect which is associated with the role of transfer revenues in stimulating local expenditure. It is implicitly understood as an irrational, ineffective increase in expenditure to finance local services at a higher level than the one that would be proportionate to the level of taxes that the local citizenry are willing to pay. There are many countries, however, which have not experienced the effect, and have perceived financial and fiscal independence in a different way. The aim of this paper is to statistically analyze the selected categories of local self-government revenues in Poland with regard to the local self-government total revenue in 2013 and the total expenditure between 1999 and 2013. The study has been based on the assumption that, from the economic, social and political vantage points, it is important that local self-government revenues should be divided into two categories, namely own revenue, in the narrow sense of the term, and transfer revenue. This approach has relied on the findings of the theory of fiscal federalism. The 15 years of local self-government at all the three tiers in Poland require a recapitulation, an assessment of the system and de lege ferenda recommendations. 


\section{Methodology of the Research}

The study involved the methods of analysis of mass phenomena dynamics such as, first of all, fixed base indexes, the average rate of change indicator and the correlation and regression coefficients from time series. The dynamics of the studied variables were presented graphically and with the use of percentage indicators. Since the analyzed data were time series by nature, which means that they were non-stationary, it was necessary to isolate the trend related to the time factor interfering with the relationships between variables. The correlation and regression coefficients from time series were calculated with the first difference method (Sobczyk, 2007, pp. 292-293). The analyzed cause-and-effect relations were of unilateral (simple) nature.

Two categories of revenue were defined for the purposes of the study: own revenue, in the narrow sense of the term, and transfer revenue. Additionally, a third category of other revenue, which eventually proved to be important for the outcome of the research, was taken into consideration. The categories defined in this way do not appear in financial reporting in Poland, where the system differs formally and legally. For the purposes of the study, it appeared to be essential to classify the revenues from the shares in state taxes, the personal income tax (PIT) and the corporate income tax (CIT), as transfer revenues. In the theory of fiscal federalism, this category of revenue (as it was formally and legally adopted in Poland) is not regarded as own revenue, but as a general transfer from the state budget. The analysis of the three tiers of local self-government was based on the level of total expenditure and the following three categories of revenue: sensu stricto own revenue, transfers from the state budget and other revenue, which included all the revenues not ascribed to either of the first two groups. Sensu stricto own revenue was calculated by subtracting the shares in PIT and CIT from own revenue. Transfer revenue included the general subsidy, appropriated allocations from the state budged and shares in PIT and CIT. The study used data provided by the Central Statistical Office.

The categories of revenue that have been defined for the purposes of the study play a twofold role. Firstly, they are of economic, social and political importance. Secondly, they shape the finance and financial independence of local self-government. The direction of further research, including the necessary, more advanced, albeit complementary, methodology, has been outlined towards the end of the paper. 


\section{Theoretical Remarks and Stylized Facts About Self-government Finance in Poland}

At the time of severe financial constraints across the public sector, it is appropriate to tighten the correlation between the level of expenditure and the level of taxation at the local tier and to make the fiscal responsibility of local decision-makers before their voters more direct. Such circumstances make it necessary to shift the finance policy of the state in relation to local self-government towards increasing tax revenues in particular. This is important as, on the one hand, local self-governments in Poland postulate a rise in subsidies, grants and shares in PIT etc., on the other hand, there is the deficit and financial constraints in the whole of the public finance system. The proposals of changes to the system of local taxes have not resulted in a reform of own revenue in the narrow sense of the term. The problem of low independence of local self-government entities has been discussed in Poland for over 20 years. For several years, that is since the moment they were founded, the local self-government tiers above the gmina level have been criticized for their low financial independence.

The system of revenue for local self-government entities in Poland is characterized by a low fiscal importance of most local taxes and a high contribution of revenues from shares in PIT and CIT in financing local selfgovernment. Despite numerous tax titles at the level of gmina and cities with powiat status, the only tax that is fiscally important is the real estate tax. Other taxes at the gmina level (the agricultural tax, the forest tax, the tax on means of transport, the tax on civil law transactions, the tax card) have only symbolic fiscal importance in the budget. The tiers of selfgovernment above the level of gmina do not have revenues from local taxes. Their main source of revenue is in the form of shares in such state taxes as PIT and CIT (thus, these taxes effectively serve as the so-called shared taxes). It appears that, if the general subsidy and appropriated allocations are also taken into account, the level of transfer revenues is quite considerable. This is important as, in the theory of fiscal federalism, shares in state taxes are treated very similarly to any other grants (transfers) of general nature from the state budget. Alternative forms of transfers are presented in Table 1, where grants have been classified according to two criteria: the way the total amount of available funds that can be transferred as a grant is determined and the way the funds are redistributed, that is how they were shared among the local self-government entities. 
Table 1. Alternative forms of intergovernmental grant programs

\begin{tabular}{|l|c|c|c|}
\hline Method's dichotomy & \multicolumn{3}{|c|}{ Method of determining the total divisible pool } \\
\hline $\begin{array}{l}\text { Method of allocating } \\
\text { the divisible pool } \\
\text { among eligible units }\end{array}$ & $\begin{array}{c}\text { Specified share of } \\
\text { national or state } \\
\text { government tax }\end{array}$ & Ad hoc decision & $\begin{array}{c}\text { Reimbursement of } \\
\text { approved } \\
\text { expenditures }\end{array}$ \\
\hline $\begin{array}{l}\text { Origin of collection of } \\
\text { the tax }\end{array}$ & A & n.a. & n.a. \\
\hline Formula & B & F & n.a. \\
\hline $\begin{array}{l}\text { Total or partial reim- } \\
\text { bursement of costs }\end{array}$ & C & G & K \\
\hline Ad hoc & D & H & n.a. \\
\hline
\end{tabular}

n.a. Not applicable.

Source: Bahl \& Linn (1998, p. 633).

The presented grants types A, B, D, E and F are mainly general transfers. Transfers $\mathrm{C}, \mathrm{G}$ and $\mathrm{K}$ are supposed to totally or partially cover the expenses, therefore they are mostly appropriated. Certain shares in state taxes are regarded as a form of general grant from the state budget which, depending on the method of allocation, may perform additional functions. Shares in a state tax are some form of a general transfer from the state budget as first they need to be accumulated in the budget and then redistributed according to the rules that were stipulated earlier. As in the case of typical general grants, local self-government is at liberty to spend funds from shares in taxes. Subsidies frequently tend to resemble shares in their character. This occurs when, in order to guarantee a certain level of transfer, its total amount is related to the "percentage" of state budget revenues from taxes. Transfer type A, which involves the transfer of shares that are in proportion to the taxes paid by the residents of a given territorial unit, is referred to as "pure" shares in state taxes. The system is characterized by the fact that local governments do not have control over either the percentage level of the shares or the formal and legal structure of the taxes in which the shares are determined. The type of taxes in which the shares are determined is an important issue as the main drawback of the "pure" shares system is that it does not equalize disparities in the level of revenue between individual local self-government entities. It may also make the level of revenue sensitive to the fluctuations of the economic situation. Direct and indirect taxes are characterized by different territorial distribution and different vulnerability to the fluctuations of the economic situation. Substantial differences in the territorial distribution of revenues from the value added tax in Poland have been raised as one of the main arguments against granting shares in the revenues from this tax to local self-government entities. 
Every system of financing local self-government must take into account the use of non-own revenues in the form of subsidies and grants from the state budget. Self-financing, that is financing based solely on own revenues, is impossible for many reasons. Transfers from the state budget traditionally perform an equalization and redistribution function and provide funding for important public services at the acceptable standard. Today they also play a key role in solving problems of the fiscal gap in the decentralized system which is caused by the fact that self-government tiers have been burdened with a considerably wide range of expensive public services. The transfer of tasks onto a lower tier has not always been followed by an adequate transfer of revenues. The fiscal gap also grows wider due to traditionally low fiscal efficiency of local taxes and charges.

Since subsidies and grants can be designed to take different forms, their functions can also vary substantially. Revenues in the form of transfers from the state budget have numerous advantages in this context. It was these advantages that were taken into consideration while founding selfgovernment poviats and voivodeships as they were granted revenues in the form of shares in state taxes. There are many reasons why such revenues are beneficial in the situation of, for example, numerous, yet fiscally inefficient, local taxes and a growing scope of communal services (spending). Another advantage of transfer revenues is the fact that they are relatively insensitive to the fluctuations of the business cycle, particularly if the percentage of the state budget revenue that is spent on subsidies has been defined by law. The administrative costs of the shares "solution" are relatively low and the recipients enjoy independence in spending. In practice, the structure and specific algorithms of general grants include elements of equalization and of appropriated transfers at the same time.

In the debates over designing the financing system and the state finance policy towards local self-government, local taxes and grants from the state budget are juxtaposed as essentially different economic sources of revenue. An extensive use of subsidies, grants and shares, which are various revenues of transfer nature, has numerous consequences, inclusive of those that were not originally foreseen by the donator (Blöchliger \& Petzold, 2009). Another major practical problem is caused by the demotivating consequences of equalization transfers, which also stimulate total expenditure.

Although the research into local self-government finance covers a wide range of issues, some trends have become predominant:

- issues of conditions for and consequences of decentralization (De Mello, 2000; Ebel \& Yilmaz, 2002; Shah, 2004, Ashworth et al., 2013); 
- issues of designing a system of financing local self-government in the context of financial autonomy and independence (Tiebout, 1956; Joumard \& Kongsrud, 2003; Raich, 2005; Surówka, 2014);

- the scope and functions of grants from the state budget and their consequences (Boyne, 1990; Grossman, 1990; Smart, 1998; Breton \& Franschini, 2004; Johansson, 2003; Feld \& Schaltegger, 2005);

- issues of the "flypaper effect" and fiscal illusions (Turnbull, 1998; Worthington \& Dollery; Arvate et al., 2009);

- efficiency of self-government and local services (Alfonso \& Fernandes, 2008; Weingast, 2009; Lockwood, 2005; Zioło, 2012).

Debates over the scope and role of transfer revenues (various grants and subsidies from the state budget) have a long tradition, especially in fiscal federalism (Oates, 1972, 1999; Musgrave \& Musgrave, 1973, Stiglitz 1988). They regard, first of all, the functions and consequences of such transfers. The results of preliminary research on Poland seem to reveal certain negative consequences of a large scope of transfer revenues. These include a break in the relationship between fiscal responsibility and spending policy, the origin and perpetuation of fiscal illusions and demanding attitudes towards state authorities (Guziejewska, 2014).

\section{The Structure and Dynamics of Specified Revenues}

This study of the structure and dynamics of specified categories of revenues is based on the juxtaposition between the structure of revenue in a stationary approach in 2013 and the dynamics of the revenue between 1999 and 2013.

As shown in Table 2, the present structure of the analyzed revenues is characterized by a great diversity across the individual tiers of selfgovernment. Therefore, an analysis of all the tiers together was omitted further in the study. Cities with poviat status and gminas are characterized by the highest level of financial independence which is calculated by the proportion of own revenue in the narrow sense of the term in total revenue. All the tiers demonstrate a high, over 50\%, level of transfer revenues from the state budget. Voivodeships and poviats have the lowest financial independence. In poviats, transfer revenues amount to $77.9 \%$ while in voivodeships, apart from transfers from the state budget (60\%), other revenues (32.5\%) serve as an important source of funding. This specific interference in the structure and dynamics of revenues in voivodeships is caused by a high increase in the grants in the so-called paragraphs 200 and 620. These 
are appropriated allocations which are granted within the framework of the EU funding schemes.

Table 2. Percentage of selected categories of local self-government revenues in total revenues of individual tiers in 2013

\begin{tabular}{|c|c|c|c|c|c|}
\hline $\begin{array}{c}\text { Structural } \\
\text { indicators }\end{array}$ & Total & Gminas & $\begin{array}{c}\text { Cities with } \\
\text { poviat } \\
\text { status }\end{array}$ & Poviats & $\begin{array}{c}\text { Voivode- } \\
\text { ships }\end{array}$ \\
\hline Total revenue & $100 \%$ & $100 \%$ & $100 \%$ & $100 \%$ & $100 \%$ \\
\hline $\begin{array}{c}\text { Own revenue in } \\
\text { the strict sense }\end{array}$ & $28,9 \%$ & $31.2 \%$ & $36.8 \%$ & $14 \%$ & $7.5 \%$ \\
\hline $\begin{array}{c}\text { Transfers from } \\
\text { state budget }\end{array}$ & $62.1 \%$ & $63.3 \%$ & $55.1 \%$ & $77.9 \%$ & $60 \%$ \\
\hline Other revenues & $9 \%$ & $5.5 \%$ & $8.1 \%$ & $8.1 \%$ & $32.5 \%$ \\
\hline
\end{tabular}

Source: own calculations based on Statistical Yearbooks of the Republic of Poland in the years 2000-2014.

This structure of revenues was formed as a result of a long evolution. The analysis of dynamics of revenues, which is based on fixed base and chain base indices, reveals steady trends in the fixed base approach and great fluctuations on a year-over-year basis. Figures 1 and 2 present the dynamics of selected categories of revenue and total expenditure at the basic tier of gminas in two approaches. The analysis of fixed base indexes demonstrates that, from 2003 onward, the dynamics of total revenue, transfer revenue and expenditure exceeded the dynamics of own revenue in the narrow sense of the term. With the exception of 2010, the dynamics of transfer revenues exceeded the dynamics of expenditure, which does not prove the stimulating effect of transfers on spending in the case of gminas. The dynamics calculated with the use of chain base indexes are characterized by high fluctuations and the absence of clear trends. Therefore, the graphical presentation has been limited to gminas only (Figure 2). 
Figure 1. Dynamics of selected revenues and gminas' total expenditure in \% $(1999=100)$

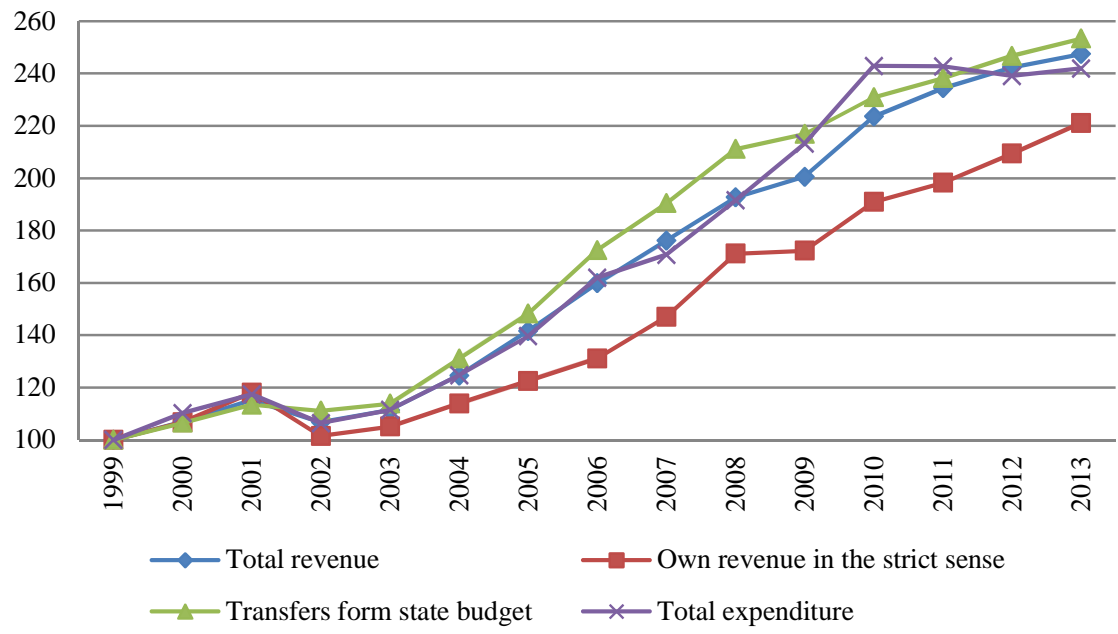

Source: own calculations based on Statistical Yearbooks of the Republic of Poland in the years 2000-2014.

Figure 2. Dynamics of selected revenues and gminas' total expenditure in \% (last year $=100$ )

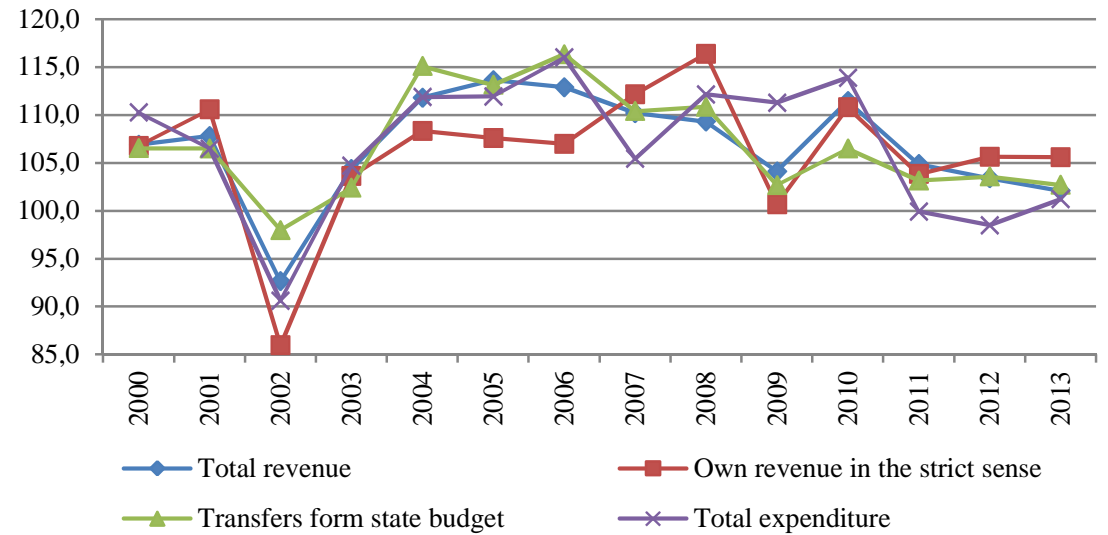

Source: own calculations based on Statistical Yearbooks of the Republic of Poland in the years 2000-2014. 
Figures 3-5 present the dynamics of selected budget categories for the tiers above the gmina level: cities with poviat status, poviats and voivodeships. In cities with powiat status, the dynamics of both total expenditure and own revenues exceeded the dynamics of transfer revenues (Figure 3). As in the case of voivodeships, the category of other revenue, which is associated with the funds obtained from the European Union, plays an important role. It has high dynamics, especially after 2008, and amounts to $8 \%$ of total revenue in cities with poviat status. The situation in these entities is, however, better than in the others thanks to the highest proportion of own revenue in total revenue (see: Table 1).

Figure 3. Dynamics of selected revenues and total expenditure in cites with poviat status in \% $(1999=100)$

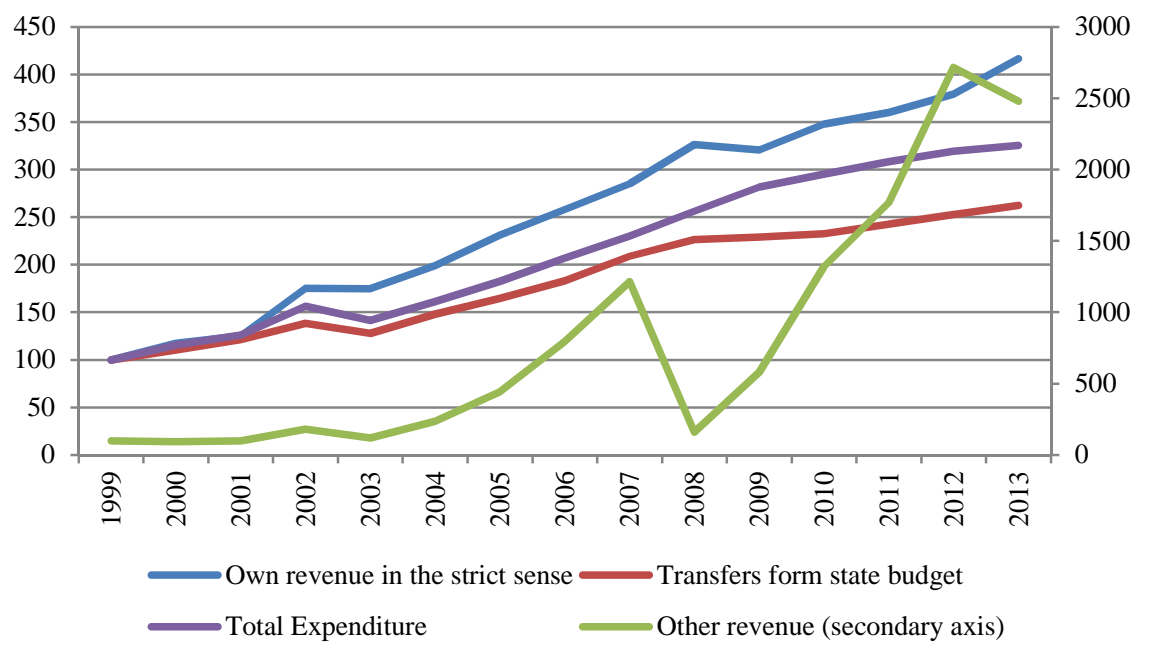

Source: own calculations based on Statistical Yearbooks of the Republic of Poland in the years 2000-2014.

The financial situation of poviats and voivodeships is characteristic as both the tiers demonstrate a very low level of financial independence with concurrent high dynamics of own revenues. This is due to a low level of own revenues in the reference year, which was also the year when the selfgovernment tiers above the gmina level were founded in Poland. These entities are characterized by high dynamics of own revenue in the narrow sense of the term and high dynamics of other revenues, especially after 2007 (Tables 4 and 5). 
Figure 4. Dynamics of selected revenues and poviats' total expenditure in \% $(1999=100)$

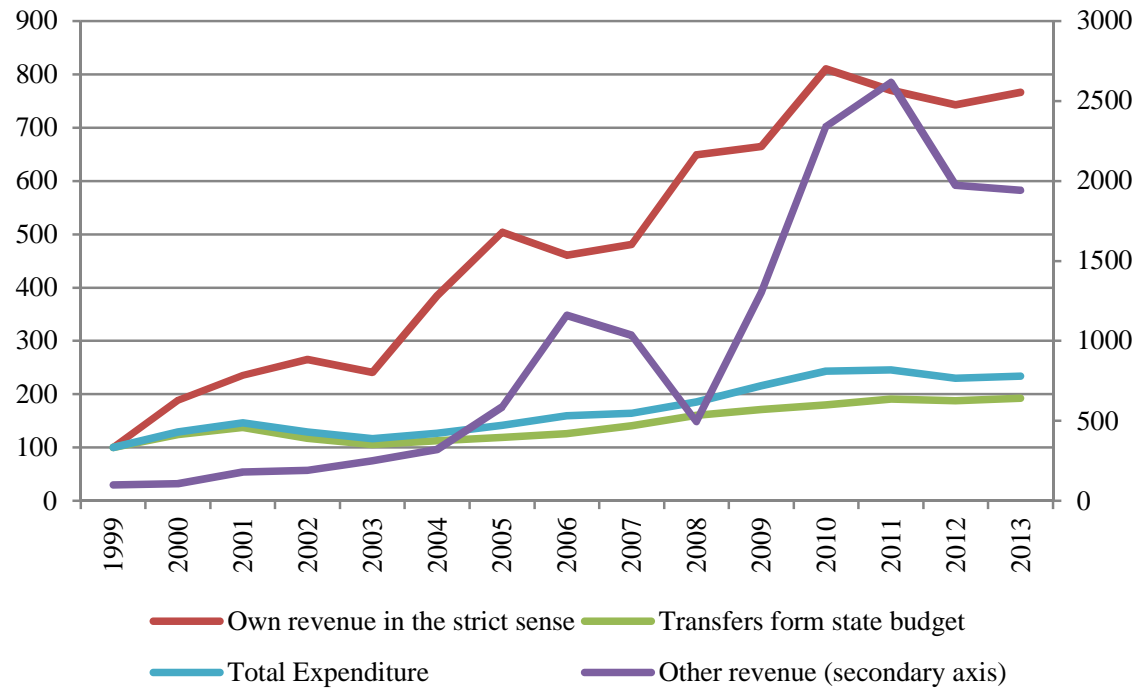

Source: own calculations based on Statistical Yearbooks of the Republic of Poland in the years 2000-2014.

Figure 5. Dynamics of selected revenues and Voivodeships' total expenditure in \% $(1999=100)$

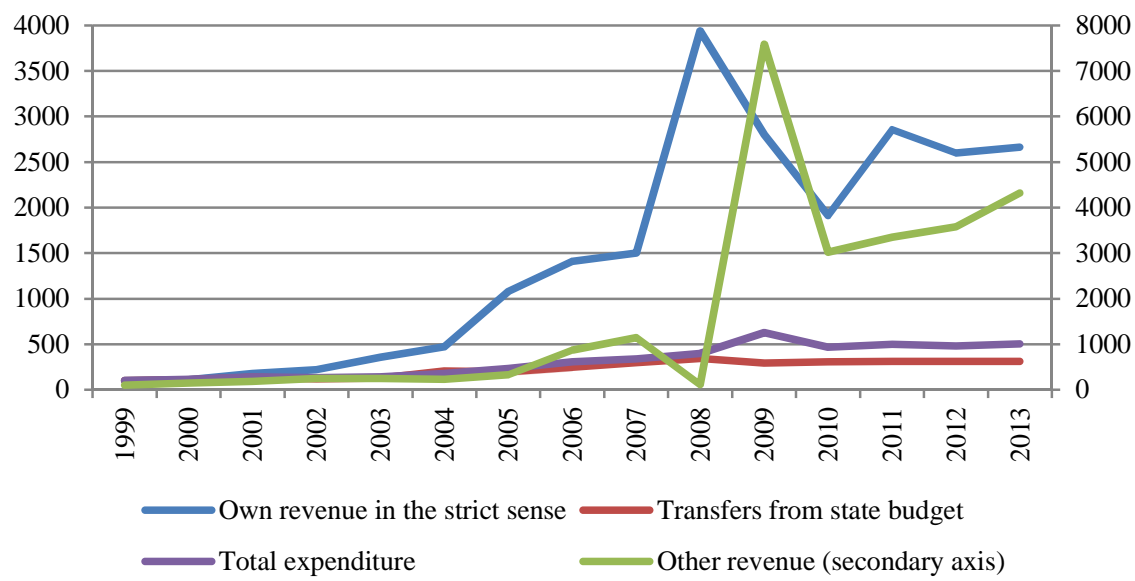

Source: own calculations based on Statistical Yearbooks of the Republic of Poland in the years 2000-2014. 
Table 3 presents the dynamics of revenues at all the tiers in a synthetic approach as an average rate of change of the phenomenon in time calculated with the following formula:

$$
\bar{y}=\sqrt[n-1]{\frac{y_{n}}{y_{1}}}
$$

These results mean that, on average, the individual variables increased year over year at the rate of over 100. It is necessary, however, to remain cautious while interpreting the average rate of change as the analyzed time series reveal some atypical observations. It is important for an interpretation of this average rate of change to compare it to the structure indicators in Table 2. Despite the high average rate of increase in own revenue in poviats and voivodeships, the two tiers demonstrate a very low level of financial independence. They are also characterized by high indicators of a rise in other revenues. The interpretation of the data in the context of the stability of the revenue system leads to an even more unfavourable assessment of the financial situation of the tiers above the gmina level.

Table 3. Average rate of change in selected categories of revenues and total expenditure in 1999-2013

\begin{tabular}{|l|c|c|c|c|}
\hline $\begin{array}{c}\text { Categories of } \\
\text { variables }\end{array}$ & $\begin{array}{c}\text { Gminas } \\
(\overline{\mathbf{y}})\end{array}$ & $\begin{array}{c}\text { Cites with poviat } \\
\text { status }(\overline{\mathbf{y}})\end{array}$ & $\begin{array}{c}\text { Poviats } \\
(\overline{\mathbf{y}})\end{array}$ & $\begin{array}{c}\text { Voivodeships } \\
(\overline{\mathbf{y}})\end{array}$ \\
\hline Total revenue & 106.7 & 108.9 & 106.3 & 112.0 \\
\hline $\begin{array}{l}\text { Own revenue in } \\
\text { the strict sense }\end{array}$ & 105.8 & 110.7 & 115.7 & 126.4 \\
\hline $\begin{array}{l}\text { Transfers form } \\
\text { the state budget }\end{array}$ & 106.9 & 107.1 & 104.8 & 108.5 \\
\hline Other revenues & 110.8 & 125.8 & 123.6 & 130.9 \\
\hline $\begin{array}{l}\text { Total expendi- } \\
\text { ture }\end{array}$ & 106.5 & 108.8 & 106.3 & 112.3 \\
\hline
\end{tabular}

Source: own calculations based on Statistical Yearbooks of the Republic of Poland in the years 2000-2014. 


\section{Correlation Between Specified Variables and Regression Analysis}

Two categories of revenues were taken into account in the analysis of correlations and the regression equations: sensu stricto revenues and transfers revenues. The category of "other" revenues has been omitted due to their specificity, the lack of homogeneity in the economic sense and the lack of references to such a category in the theory of self-government finance. The results of the correlation between the variables at the individual tiers have been presented in Table 4 .

Table 4. Pearson's correlation coefficients for selected variables

\begin{tabular}{|c|c|c|c|c|}
\hline $\boldsymbol{r}_{\boldsymbol{x y}}$ & Gminas & $\begin{array}{c}\text { Cities with } \\
\text { poviat status }\end{array}$ & Poviats & Voivodeships \\
\hline$r_{\text {own revenues/expenditure }}$ & 0.56 & 0.50 & 0.51 & 0.06 \\
\hline$r_{\text {transfers/expenditure }}$ & 0.67 & 0.76 & 0.81 & -0.25 \\
\hline
\end{tabular}

Source: own calculations based on Statistical Yearbooks of the Republic of Poland in the years 2000-2014.

In the case of gminas, cities with poviat status and poviats, there is a moderate correlation between own revenue and expenditure and a relatively high correlation between transfer revenues from the state budget and expenditure, which means that these entities have limited financial independence and very limited possibilities of exercising their own financial policy with regard to both revenue and expenditure. The voivodeships, which experienced a high increase in expenditure due to the surge of EU funds classified as other revenue, are in a peculiar situation. This tier experienced high fluctuations in revenues in all the categories, which was related to numerous systemic changes and the changes in the reporting of EU funds. Moreover, the funds have always accounted for a substantial portion of budgetary funds. In the statistical analysis, no correlation was observed between own revenue and expenditure and negative correlation was noted between transfers and total expenditure.

An analysis of regression was the next step. Table 5 presents the results of regression for the entities where statistical significance was observed using significance $F$ and $P$-values (the outcomes where both the indicators $\geq 0.05$ were rejected). The study used the data after the trend line was eliminated with the first difference method. 
Table 5. Summary output of regression statistics

\begin{tabular}{|c|c|}
\hline \multicolumn{2}{|c|}{ Gminas } \\
\hline $\begin{array}{l}\text { Own revenues as independent vari- } \\
\text { able }\end{array}$ & $\begin{array}{l}\text { Transfers from state budget as independ- } \\
\text { ent variable }\end{array}$ \\
\hline Observations $15-1$ & Observations $15-1$ \\
\hline R Square 0.317 & R Square 0.446 \\
\hline Significance $F 0.036$ & Significance $F 0.009$ \\
\hline P-value 0.035 & P-value 0.009 \\
\hline The regression line is: & The regression line is: \\
\hline \multicolumn{2}{|c|}{ Cities with poviat status } \\
\hline $\begin{array}{l}\text { Own revenues as independent vari- } \\
\text { able }\end{array}$ & $\begin{array}{l}\text { Transfers from state budget as independ- } \\
\text { ent variable }\end{array}$ \\
\hline n.r. & $\begin{array}{l}\text { Observations } 15-1 \\
\mathrm{R} \text { Square } 0.577 \\
\text { Significance } F 0.001 \\
\text { P-value } 0.001 \\
\text { The regression line is: } \\
\qquad \hat{y}=981,76+1,42 x \\
\end{array}$ \\
\hline \multicolumn{2}{|r|}{ Poviats } \\
\hline $\begin{array}{l}\text { Own revenues as independent vari- } \\
\text { able }\end{array}$ & $\begin{array}{l}\text { Transfers from state budget as independ- } \\
\text { ent variable }\end{array}$ \\
\hline n.r. & $\begin{array}{l}\text { Observations } 15-1 \\
\mathrm{R} \text { Square } 0.661 \\
\text { Significance } F 0.0004 \\
\text { P-value } 0.0004 \\
\text { The regression line is: } \\
\qquad \hat{y}=221.61+1,16 x\end{array}$ \\
\hline \multicolumn{2}{|c|}{$\begin{array}{ll}\text { Voivodeships } \\
\end{array}$} \\
\hline $\begin{array}{l}\text { Own revenues as independent vari- } \\
\text { able }\end{array}$ & $\begin{array}{l}\text { Transfers from state budget as independ- } \\
\text { ent variable }\end{array}$ \\
\hline n.r. & n.r. \\
\hline
\end{tabular}

n.r. Results are not reliable.

Source: own calculations based on Statistical Yearbooks of the Republic of Poland in the years 2000-2014.

In the case of gminas, the results of regression equations demonstrate that an increase in own revenue by $1 \mathrm{~m}$ zlotys should result in a rise in expenditure by $1.97 \mathrm{~m}$ zlotys whereas an increase in transfers by $1 \mathrm{~m}$ zlotys should cause a rise in expenditure by $1.61 \mathrm{~m}$ zlotys. However, the model is accounted for by the selected categories of revenues only in $30-40 \%$, which means that other categories of revenues affect the level of expenditure in 
gminas in 60-70\%. Nevertheless, the results do not demonstrate the presence of the flypaper effect at the level of gminas.

In the case of cities with poviat status and poviats, reliable results were only obtained in the analysis of regression of transfer revenues. In cities with poviat status, an increase in transfer revenues by $1 \mathrm{~m}$ zlotys should result in a rise in expenditure by $1.42 \mathrm{~m}$ zlotys whereas in poviats there should occur a $1.16 \mathrm{~m}$ zlotys rise with high statistical significance and $\mathrm{R}^{2}=0.661$. The results of the general statistical analysis reveal that sensu stricto own revenue and transfer revenue should not be treated as independent variables that would statistically significantly affect the level of expenditure in voivodeships. The level of expenditure in the case of gminas, cities with poviat status and poviats is defined, to a large extent, by transfer revenues. Additional analyses of regression that were conducted for voivodeships demonstrated high statistical correlation between the other revenue variable and total expenditure ( $\mathrm{r}=0.92$ after the line trend was eliminated, $\mathrm{R}^{2}=0.74$, $\mathrm{X}$ variable $1=0.82$ ). In cities with poviat status, the results for these variables do not demonstrate any correlation. While in this case the results can be explained by the narrow range and high fluctuations in time of these revenues, no correlation revealed between the independent variable, own revenue, and dependent variable, total expenditure, require further research. At this stage, the results are surprising and an interpretation is difficult, if not impossible. One of the plausible explanations of the results is the high importance of EU funds in the budgets of cities with poviat status and voivodeships.

\section{Conclusions}

The analysis of the structure of local self-government revenues in Poland in the context of the theory of fiscal federalism reveals the dominant role of transfer revenues from the state budget. The highest share of these revenues in financing occurs in the tiers above the gmina level: poviats (77.9\%) and voivodeships $(60 \%)$. The most favourable indicators are demonstrated by cities with powiat status, where sensu stricto revenues amount to $36.6 \%$ and transfers from the state budget stand at $55.1 \%$. The analysis of the structure and dynamics which is based on fixed base indices reveals high dependence of budget revenues of cities, poviats and voivodeships on the revenues from the inflow of EU funds and appropriated funds. No clear symptoms of the flypaper effect are noticeable, however, the high dynamics of own revenues at the tiers above gmina level are observed in the analysis. This is due to a very low starting level of these revenues in 1999. The interpretation of the 
dynamics of revenues presented graphically must include the aforementioned element and other quality elements. The juxtaposition of the analysis of the dynamics and the structure indicators reveals very weak financial foundations of nearly all tiers of local self-government although gminas and cities with poviat status seem to be in the best position. Therefore, recognizing the benefits and the important role of transfer revenues in the system of local self-government finance, it is necessary to point to the threats of too small a base for an independent financial policy which would be measured by the level of own revenues in the narrow sense of the term.

The outcomes of the analysis of regression demonstrate that own revenues and transfer revenues may be treated as independent variables which influence the level of expenditure only at the gmina tier. However, this model can only be accounted for by the selected categories of revenues in $30-40 \%$. In the case of cities with poviat status and poviats reliable result were obtained only in the analysis of regression of transfer revenues. In cities with poviat status, an increase in transfer revenues by $1 \mathrm{~m}$ zlotys results in a rise in expenditure by $1.42 \mathrm{~m}$ zlotys whereas in poviats there should occur a $1.16 \mathrm{~m}$ zlotys rise with high statistical significance and $\mathrm{R}^{2}=$ 0.66 . The results of the general statistical analysis reveal that sensu stricto own revenues and transfer revenues should not be treated as independent variables which would statistically significantly affect the level of expenditure in voivodeships. The additional analysis of regression for "other" revenue demonstrated high statistical correlation between the other revenue variable and total expenditure. The outcomes of the analysis of regression at all the tiers are highly affected by the revenues in the other category, which are characterized by high general dynamics and fluctuations year over year.

The conclusions from the research have preliminarily practical implications. The category of revenue that, for the purposes of the study, was defined as "other" includes, first of all, EU funds and allocations from appropriated funds, agencies etc. These revenues are of incidental nature, as they are a specific, transient source of financing local self-government. In the context of alternative forms of subsidizing presented in Table 1, they have the features of ad hoc grants, which, however, do not come from the state budget, but from the outside sources that are associated with the EU membership. Once these sources have been exhausted, there is a threat of serious turbulences in the financial economy of self-government. This assessment will be even more unfavourable if the dynamics of local selfgovernment debt and infrastructural investments, which may generate high costs of operation and maintenance, are taken into account. 
The results of the study also point to a necessity of further research which would focus on two aspects in particular. Firstly, it is necessary to conduct quality research, the aim of which would be to study non-financial consequences of a given system of finance in the context of origin and perpetuation of fiscal illusions. Secondly, there is a need for more in-depth econometric research which would use the latest methods of co-integration analysis. The use of simple statistical methods to assess the efficiency of the system of finance provides a certain overall representation. Some outcomes, however, are difficult to interpret in depth and more substantively. Therefore, further research is required with the use of more advanced methods.

\section{References}

Afonso, A. \& Fernandes, S. (2008). Assessing and explaining the relative efficiency of local government. Journal of Socio-Economics, 37(5). http://dx.doi.org/10.1016/j.socec.2007.03.007.

Arvate, P. R., Avelino, G. \& Tavares J. (2008). Fiscal conservatism in a new democracy: "Sophisticated" versus "naïve" voters. Economics Letters, 102(2). doi:10.1016/j.econlet.2008.11.030.

Ashworth, J., Galli, E., \& Padovano, F. (2013). Decentralization as a constraint to Leviathan: a panel cointegration analysis. Public Choice, 156(3). http://dx.doi.org/10.1007/s11127-012-9962-8.

Bahl, R., \& Linn, J. (1998). Fiscal Decentralization and Intergovernmental Transfers in Less Developed Countries, In W. E. Oates (Ed.) The Economics of Fiscal Federalism and Local Finance, Massachusetts: Edward Elgar Publishing Inc.

Blöchliger, H. \& Petzold, O. (2009). Taxes and Grants: On the Revenue Mix Of Sub-National Governments, OECD Network on Fiscal Relations Across Levels of Government. Retrieved from http://www.oecd.org/tax/federalism/ 42783028.pdf (01.04.2015).

Boyne, G. A. (1990). Central Grants and Local Policy Variation. Public Administration, 68.

Breton, A. \& Franschini, A. (2004). Intergovernmental equalization grants: some fundamental principles, Department of Public Policy and Public Choice, Working Paper N.42, Retrieved from http://polis.unipmn.it/pubbl/RePEc/uca /ucapdv/fraschini42.pdf (01.04.2015).

Ebel, R. D. \& Yilmaz, S. (2002). On the Measurement and Impact of Fiscal Decentralization, World Bank Policy Research Working Paper, Retrieved from http://www1.worldbank.org/publicsector/LearningProgram/Decentralization/M easurementImpact.pdf (01.04.2015). 
Guziejewska, B. (2014). Dochody transferowe dla samorządu terytorialnego w polityce finansowej państwa. Aspekty teoretyczne a wyzwania bieżące. Finanse Komunalne, 1-2.

Grossman, P. J. (1990). The Impact of Federal and State Grants on Local Government Spending: a Test of the Fiscal Illusion Hypothesis, Public Finance Review, 18(3). http://dx.doi.org/10.1177/109114219001800304.

Lockwood, L. (2005). Fiscal Decentralization: A Political Economy Perspective, Warwick Economic Research Papers No.721, Retrieved from http://www2.warwick.ac.uk/fac/soc/economics/staff/blockwood/handbook.pdf (01.04.2015).

De Mello, L. R. (2000). Fiscal Decentralization and Intergovernmental Fiscal Relations: A Cross-Country Analysis. World Development, 28(2).

Musgrave R. A., \& Musgrave, P. B. (1973). Public Finance in Theory and Practice, McGraw -Hill Book Company.

Johansson, E. (2003). Intergovernmental Grants as a Tactical Instrument: Empirical Evidence from Swedish Municipalities. Journal of Public Economics, 87(5-6). http://dx.doi.org/10.1016/S0047-2727(01)00148-7.

Joumard, I. \& Kongsrud, P. M. (2003). Fiscal relations across government levels. "OECD Economic Studies" 2003/1, no. 36.

Oates, W. E. (1972). Fiscal Federalism, New York: Harcourt Brace Jovanovich.

Oates, W. E. (1999). An Essay on Fiscal Federalism. Journal of Economic Literature, 37.

Raich, U. (2005). Fiscal Determinants of Empowerment. World Bank Policy Research Working Paper 3705.

Shah, A. (2004). Fiscal Decentralization in Developing and Transition Economies, World Bank Policy Research Working Paper 3282, Retrieved from http://siteresources.worldbank.org/PSGLP/Resources/FiscalDecentralizationin DevelopingandTransition.pdf (01.04.2015).

Sobczyk, M. (2007). Statystyka, Warszawa: PWN.

Smart, M. (1998). Taxation and Deadweight Loss in a System of Intergovernmental Transfers. Canadian Journal of Economics, 31(1). http://dx.doi.org/10.2307/136384.

Statistical Yearbooks of the Republic of Poland 2000-2014, Warsaw: Central Statistical Office of Poland.

Stiglitz, J. E. (1988). Economics of the public sector. New York, London: W.W. Norton\&Company.

Surówka, K. (2014). Ograniczenia faktyczne samodzielności finansowej jednostek samorządu terytorialnego - degresja samodzielności finansowej. Finanse Komunalne, 1-2.

Tiebout, Ch. (1956). A pure Theory of Local Expenditure, Journal of political economy, 64.

Turnbull, G. K. (1998). The Overspending and Flypaper Effects of Fiscal Illusion: Theory and Empirical Evidence. Journal of Urban Economics 44(1). http://dx.doi.org/10.1006/juec.1997.2056. 
Weingast, B. R. (2009). Second generation fiscal federalism: The implications of fiscal incentives, Journal of Urban Economics, 65(3). http://dx.doi.org/10.10 16/j.jue.2008.12.005.

Worthington, A. C. \& Dollery, B. E. (1997). Fiscal Illusion and the Australian Local Government Grants Process: How Sticky is the Flypaper Effect? Public Choice, 99(1/2).

Zioło, M. (2012). Modelowanie źródet finansowania inwestycji komunalnych a efektywność wydatków publicznych, Warszawa: CeDeWu. 
